\title{
THE
}

\section{Employment Type, Residential Status, and Consumer Financial Capability: Evidence from China Household Finance Survey}

Xu Cui

University of Rhode Island

Jing Jian Xiao

University of Rhode Island, jjxiao@uri.edu

Jingtao Yi

Follow this and additional works at: https://digitalcommons.uri.edu/hdf_facpubs

The University of Rhode Island Faculty have made this article openly available.

Please let us know how Open Access to this research benefits you.

This is a pre-publication author manuscript of the final, published article.

Terms of Use

This article is made available under the terms and conditions applicable towards Open Access

Policy Articles, as set forth in our Terms of Use.

\section{Citation/Publisher Attribution}

Cui, Xu, et al. "Employment Type, Residential Status, and Consumer Financial Capability: Evidence from China Household Finance Survey." The Singapore Economic Review, vol. 64, no. 1, 2019, pp. 57-81. doi: 10.1142/S0217590817430032

Available at: https://doi.org/10.1142/S0217590817430032

This Article is brought to you for free and open access by the Human Development and Family Science at DigitalCommons@URI. It has been accepted for inclusion in Human Development and Family Science Faculty Publications by an authorized administrator of DigitalCommons@URI. For more information, please contact digitalcommons-group@uri.edu. 


\title{
Employment Type, Residential Status, and Consumer Financial
}

\author{
Capability: Evidence from China Household Finance Survey \\ Xu Cui \\ School of Business \\ Renmin University of China \\ Department of Human Development and Family Studies \\ University of Rhode Island \\ billcui work@ruc.edu.cn \\ Jing Jian Xiao \\ Department of Human Development and Family Studies \\ University of Rhode Island \\ jixiao@uri.edu \\ Jingtao $\mathrm{Yi}^{\mathrm{a}}$ \\ School of Business \\ Renmin University of China \\ yijingtao@rbs.ruc.edu.cn
}

\section{Abstract}

Research on consumer financial capability is important for consumer financial wellbeing and emerging in the literature. However, studies on consumer financial capability in the Chinese context remain limited. To fill up the research gap, we used data from the 2011 China Household Finance Survey to investigate whether employment type and residential status were associated with consumer financial capability in China. Consumer financial capability was measured by the range of financial assets. Results from OLS and Poisson regressions showed that people employed in the government-managed system, with urban residence registration, and with non-local rural residence registration had a better financial capability than their respective counterparts. The results have policy implications for improving consumer financial education and supporting vulnerable consumers.

\footnotetext{
a Corresponding author.
} 
Keyword: China Household Finance Survey, Financial Capability, The Government-managed System, Household Residence Registration

JEL Classifications: D140 R230 


\section{Introduction}

Consumer financial capability refers to individual ability to apply appropriate financial knowledge and perform desirable financial behavior to achieve financial wellbeing (Atkinson et al. 2006; Lusardi and Mitchell, 2014; Xiao et al. 2014). Social movements promoting financial capability started first in developed countries (Lusardi and Mitchell, 2011; OECD, 2016) and then occurred in developing countries. In China, the People's Bank of China launched the Financial Literacy Promotion Program in 2013 and set September as the Financial Literacy Month every year (The Peoples' Bank of China, 2013). The program has made a call for research on consumer financial capability in China. Yin et al. (2014) found that the proportion of Chinese who correctly answered financial literacy questions was very low, with no more than $30 \%$ for each question. In comparison, consumers in the U.S. (Lusardi and Mitchell, 2011) and European countries (OECD, 2016) on average have better financial literacy levels than Chinese consumers, which implies Chinese consumers need more financial education and protection. The purpose of this study is to examine factors associated with consumer financial capability measured by the household financial asset range using data from a large sample in China.

Research on consumer financial capability in China is limited mainly because of lack of data. The China Household Financial Survey (CHFS) has provided opportunities for researchers to study this topic with Chinese data. To our knowledge, research on financial capability with the CHFS data is limited. This study contributes to the research literature by examining factors associated with financial capability from the perspective of background risks in China and focusing on two independent variables that have unique 
Chinese features, the employment type and residence registration status. ${ }^{2}$ In China, people are employed in two major labor markets, the state-owned units and non-stateowned units (National Bureau of Statistics of China, 2016). The state-owned unit is a government-managed system including positions in civil service, public institutions, the military, and state-owned enterprises. The non-state-owned unit is a non-government managed system, such as collective and private-owned enterprises. Two systems have major differences in terms of job security, income stability, and work related benefits. We would like to examine if there are differences in financial capability between people working in these two types of systems.

The other unique independent variable is the household residency registration status (hukou) (National People's Congress of the People's Republic of China, 1958). In China, people living in rural and urban areas are recorded in two different household residence registration systems. People with urban and rural household registrations receive different treatments in terms of job and life opportunities and benefits. In addition, people with local and non-local household registrations receive differential treatments of job and life opportunities and benefits. In this study, we would like to see if there are any differences in financial capability between people with urban and rural household registrations and with local and non-local household registrations.

\footnotetext{
2 Although there are other perspectives besides background risks, such as financial knowledge, skills and habits, since they are not the focus of this study, we included these variables in the model as control variables, which are having an undergraduate degree or higher, working in the financial service sectors, using credit cards, different preferences of risks, and the preference for future vs. current consumption.
} 
We found employees in the government-managed working system and people with urban residence registration, who represented groups with low background risks, had better financial capability. Among people with rural registrations, non-local people had better financial capability than their local counterparts. As for controlled factors, we found consumers with young age, having low income, without undergraduate or higher degree, not using a credit card, working in non-financial service occupations, and living in the northeast region tended to have a lower level of financial capability. Our findings provide useful information for consumer policy makers and educators to identify vulnerable consumers in terms of financial capability and deliver pertinent financial education to them.

The remainder of this paper is organized as follows: section 2 presents literature reviews and hypotheses, section 3 introduces the method including data description and analysis strategy, section 4 presents the results, section 5 provides the robustness checks, and section 6 concludes.

\section{Literature Review and Hypotheses}

\subsection{Defining Financial Capability}

Financial capability is defined differently in the research literature. Financial capability is a multidimensional concept that examines individual ability from various angles such as knowledge, habits, statuses, and access (Lin et al., 2016). Financial literacy is one main area of financial capability (Lusardi and Mitchell, 2011). Abreu and Mendes (2010) defined financial literacy as specific financial knowledge, the investors' educational level, and the sources of information commonly used by investors as the basis for their financial choices. 
Lusardi and Mitchell (2014) used term "financial literacy" to represent individual ability to process economic information and make informed decisions about financial planning, wealth accumulation, debt, and pensions. Some scholars preferred to include more dimensions to measure financial capability. Atkinson et al. (2006) used a set of financial behaviors and a set of applied financial literacy questions called a "money quiz" to measure financial capability. Taylor (2011) defined financial capability as people's knowledge of financial matters, their ability to manage their money and to take control of their finances. His financial capability indicator was composed of measures of financial behaviors and statuses. Xiao et al. $(2014 ; 2015)$ defined consumer financial capability as applying financial knowledge and engaging in desirable financial behavior to achieve financial wellbeing. Previous research suggested that financial capability should include three elements: financial literacy, financial behavior, and financial status.

Unlike previous studies that used multiple measures for financial capability, we used the household financial asset range to measure financial capability. We believed this measure was unique and a good proxy as it measured financial capability from all three perspectives: financial literacy, financial behavior, and financial status. This unique measure was supported by previous research.

First, a broader household financial asset range indicates a more sophisticated financial literary. To build a more diversified portfolio of investment, more comprehensive financial knowledge is needed, as shown by researchers who found positive correlations between financial literacy and portfolio diversification (Guiso and Jappelli, 2008; Abreu and Mendes, 2010), stock-market participation (Georgarakos and Inderst, 2011; van Rooij 
et al., 2011) and risky asset share conditional on participation (Jappelli and Padula, 2015).

This is consistent with Robb and Woodyard (2011) where they found financial knowledge and best practice behavior were highly correlated.

Second, holding a broad financial asset range is a desirable financial behavior. Based on the portfolio diversification theory developed by Markowitz (1952), economic theories and finance curriculums encourage people to hold a well-diversified portfolio for a best mean return and variance combination. In the investment theory, investment diversification is the rule of thumb to minimize one's risk (Deidda, 2014). We believe holding a broad household financial asset range is a desirable financial behavior.

Third, financial status is positively correlated with portfolio diversification. Tsigos and Daly (2016) found risk tolerance increases significantly with wealth. Wealthier people tend to invest more on risky assets (Cardak and Wilkins, 2009) and have more diversified financial portfolio. In summary, research indicates that consumers with more sophisticated financial capability tend to have a broader household financial asset range.

The two alternative variables that might be used to measure financial capability are the share of financially risky assets in the total portfolio and the market value of financially risky assets (see Yin et al., 2014). However, we chose not to use them because the household financial asset range measure has several advantages over them. First, the market value of each financially risky asset usually fluctuated every business day, which creates difficulties for comparison at different interview dates. The survey lasted for more than eight months. The values over such a long period of time might not be comparable. Second, the market value of financially risky asset owned by interviewees was either an 
approximation or was provided in ranges in the data. Interviewees might have difficulty remembering the amount of their financially risky assets if they owned several types. Third, the interviewees might not want to give true information about the amount of their assets. The household financial asset range does not rely on this data to the same extent. The household financial asset range is comparable over time. Compared to the ability of the interviewees to know the market value of their financially risky assets, it is easier for them to remember how many types of these assets were in their portfolios. Also, the interviewees might not want to reveal the market value of their financially risky assets and were more likely to state how many types of financial risky assets they owned. In general, while both market value and share of financially risky assets are useful, the reliability of the data on the share of financially risky assets in the total portfolio provides more realistic information and thus is more useful to study, despite the fact that some valuable information may be lost.

\subsection{Employment Type and Financial Capability}

Cardak and Wilkins (2009) suggested people tended to avoid risks related to holding financially risky asset such as stocks when they had background risks deriving from labor income uncertainty, business income, health status and committed expenditures and provide empirical test in the Australian context. In the context of China, two major background risks of households come from the employment type and household residence registration system. In China, people work in either a government-managed system (referring to "in the system" in this paper) or not. There are two groups of employees in the system, one refers to those having bianzhi and the other refers to those 
working in the state-owned enterprises. Bianzhi can be translated as "establishment of posts" (Brødsgaard, 2002). People who have bianzhi are fiscally dependent employees working in civil services, public institutions and the military because their income and benefits are from government budgets. In China, a position as fiscally dependent employee is highly valued and attracts millions of people, many of whom are recent graduates, taking the national and local examinations for admission to the civil service each year. In the 2017 national examination, the most popular post had a record low admission rate of 1:9837 (Chinanews, 2016). Compared to people employed in private sector positions, fiscally dependent employees tend to have higher incomes (Fu, 2014), lower income uncertainty, and opportunities to buy homes below market price. This last advantage is because their employers build apartments and sell at a relatively low price to their employees, although new employees may have to wait for 5 to 10 years depending on their rankings, work experience and other criteria to buy the houses provided by their employers. Fiscally dependent employees have a better social security network provided by employers (unemployment insurance, medical insurance and some other benefits), better pensions (Cai and Cheng, 2014), and a higher possibility that their children can become fiscally dependent employees in the same system (Han et al., 2016).

Prior to the economic reform in China, employees who worked in the state owned enterprises were considered as having an iron rice bowl, or full employment meaning that these employees could not lose their jobs regardless of their work performance and received generous fringe benefits and subsidized food supply (Shi and Mok, 2012). Even after the reform, the state-owned enterprises still remain as instruments of the state 
(Zhang and Rasiah, 2014) and assume many social responsibilities, such as maintaining employment rate and minimizing layoffs (Bai et al., 2009). State-owned enterprise workers had a stronger wage growth compared to non-state-owned enterprise workers since the implementation of the Labor Contract Law after 2008 (Cui et al., 2013). They were more likely to have health insurance (Du, 2009). Researchers found that civil servants had the highest and also the most stable hidden income, followed by employees in state owned enterprises, colleges or research institutions, and public service institutions, while people working in private sectors and foreign companies had the lowest hidden income (Gao et al., 2015).

Literatures showed that risky asset ratio was negatively associated with labor income uncertainty (Hochguertel, 2003), labor income risk (Haliassos and Bertaut, 1995), and health risk (Rosen and Wu, 2004). Pension savings had a negative effect on ratio of risky asset to safe assets (Heaton and Lucas, 2000). Based on unique characteristics of employees in the system, we propose the following hypothesis:

H1: Compared to the other type of employees, employees in the governmentmanaged system have better financial capability.

\subsection{Household Registration Status and Financial Capability}

Another Chinese specific variable that has attracted significant research interests is hukou, which can be translated as household residence registration. Hukou is a legal institution of household permanent residence registration established in 1958 (National People's Congress of the People's Republic of China, 1958), to control migration between rural and urban areas. Hukou is associated with many social benefits and rights such as buying 
homes and cars in some big cities. A detailed exposition can be found in Zhu (2003). In the earlier years of the implementation of the household residence registration system, people were not allowed to migrate to areas without local residence registration and would be sent back to their legal registered area if their registrations were non-local. The regulation became less strict after the economic reform started in 1980s and a more flexible residence registration policy was adopted (Cheng and Selden, 1994). Massive migrations emerged since the regulation was relaxed and migrant workers became major labor forces in big cities. In 2013, the number of rural migrants was 166.1 million, $12.2 \%$ of the total population of 1.36 billion and $43.4 \%$ of the urban labor force of 382.4 million (Fang and Sakellariou, 2015).

Conceptually, people could have one of four household residence registration statuses: local urban residence, local rural residence, non-local urban residence, and nonlocal rural residence (Chan and Buckingham, 2008). Each registration status is associated with different social benefits and distinctions exist between various aspects such as opportunities for jobs, education, and home and car purchases in some big cities. Some studies examined benefit inequality between rural and urban household residence registrations. Researchers found that compared to people with rural household residence registration, people with urban household residence registration had advantages in income (NBSC, 2016), social welfare, medical insurance (Zhang and Treiman, 2013), medical care costs (Zhang et al., 2016) and education (Afridi et al., 2015). College graduates with urban household residence registrations had higher starting salaries, occupations with higher salaries, and greater opportunities to obtain stable government 
jobs (Wang et al., 2016). These advantages increased urban household residence registration holders' wealth, reduced their income risks, improved financial literacy, and reduced their need to save for their children. Because people with urban household residence registrations generally had more financial experience than rural people, we expect urban household residence registration holders have better financial capability. Thus we propose the following hypothesis:

H2: People with urban household residence registration have better financial capability than people with rural household residence registration.

Researchers who looked even further into the combination of the two dimensions of rural versus urban and local versus non-local found interesting results. Based on the selfselection theory of immigrant, Xie (2012) found migrant workers with urban household residence registrations encountered no obstacles in economic integration and even performed better than local urban workers in terms of earnings and rates of return to human capital. However, after controlling for education, benefits associated with local urban household residence registration turned the balance in favor of people with local urban household residence registration. People with local urban registration received various benefits (while non-local people do not) such as access to local schools (Wong et al., 2007; Chan, 2010) and to some urban housing that were more affordable and in better condition (Wu, 2006), which greatly lowered their expenses and left them more resources for financial investment. Based on previous research, we propose the following hypothesis:

H3: People with local urban household residence registration have better financial capability than people with non-local urban household residence registration. 
Since the benefit associated with rural household residence registration was much less than that with urban household residence registration (Cui et al., 2015), local rural people receive only very limited resource advantages than non-local rural people, the household residence registration effect between local and non-local rural people is limited. Non-local rural people were a positive, self-selected group (Xie, 2012), mainly composed of young adults (Sonoda, 2014), who were more educated (Xie, 2012) and tended to have more training and to work harder than local rural people (He et al., 2015), resulting in the accumulation of more human capital to benefit financial literacy (Huston, 2010). Younger migrant workers were more confident, more optimistic, were more used to new media, and spent more (Li and Tian, 2011). These features led younger migrant workers to engage more in financial activities. He et al. (2015) found non-local rural people had higher income than local rural people, ceteris paribus. Based on previous discussions, we propose our fourth hypothesis:

H4: People with non-local rural household residence registration have better financial capability than people with local rural household residence registration.

\section{Method}

\subsection{Data}

Data used in this study was from the 2011 China Household Finance Survey (CHFS). The survey collected micro-level household information including housing asset, financial wealth, liability and credit, income, consumption, social security and insurance, intergeneration transfer, demographic statistics and employment. The survey covered 25 provinces and municipalities of China nationwide, including 80 cities and 320 villages and 
gathered data from 8,438 households and 29,324 individuals. The data of 2011 survey is available online for the public. More details about the data can be found in Gan et al. (2013).

\subsection{Variables}

In this study, the dependent variable is the financial asset range representing financial capability. In the 2011 CHFS survey, detailed data of financial assets of household is available, including demand deposits, time deposits, stocks, bonds, mutual funds, derivatives, wealth management products, non RMB denominated assets, and gold. We created 9 dummy variables for these financial asset types. A dummy variable for each type of financial asset was set to 1 if a household held that kind of asset and 0 otherwise. The financial asset range is the sum of the 9 dummy variables, with possible scores from 0 to 9. For example, if a household only holds bonds, stocks, and gold, then its financial asset range is 3 .

The focused independent variables are employment type and household residence registration status. If the interviewee works in civil service, the military, a public institution or a state-owned enterprise, a dummy variable labeled "employee in the system" was set to 1 , otherwise 0 . Two sets of dummy variables of household residence registration status were used, one set included urban registration and rural registration, and the other set included local urban registration, local rural registration, non-local urban registration, and non-local rural registration. We used the information of the household head to measure the employment type and the household residence registration status.

Following the literature, control variables were age, net household income, net 
household asset, family size, and several dummy variables including gender, marital status, finance service worker status, owning a business, owning a home, possession of a credit card, risk attitude when they were asked about investment risk preference, a set of regions, and the preference for future vs. consumption. An endogeneity problem may occur considering people living in the rural area might have less exposure to the financial institution branches, which might lead to fewer financial assets. To address this issue, we added a dummy variable indicating whether a household lives in the rural area. The endogeneity problem may also derive from the omitted variable which is the unobserved ability of individuals that may affect both government employment and financial capability. We address this issue by including a dummy variable indicating whether an individual has an undergraduate or higher degree, as a proxy of the unobserved ability of individuals. In China, the college and graduate school entrance exams are very competitive. We believe people who passed these entrance exams had better ability than others. See Table 1 for more details of variable specifications.

[Insert Table 1 here]

\subsection{Data Analysis}

Bivariate analysis and multiple OLS regressions were used for preliminary analyses to examine the relationship between financial capability and a set of independent variables. Since the type of the dependent variable is count data, the model cannot be consistently estimated with linear regression methods due to the preponderance of zeros (in this study, $37 \%$ of the observations is zero in dependent variable), and the nature of the discrete choice dependent variable (Greene, 2012). Following the tradition in dealing with count 
data, we used Poisson regression for more accurate analyses. The deviance goodness-offit tests and Pearson goodness-of-fit tests did not reject the assumption which should be satisfied for Poisson regression, meaning there was no over-dispersion (variance and mean are not equal) in the dependent variable (StataCorp, 2013).

The distribution of financial asset range follows Poisson distribution:

$$
\mathrm{P}(\mathrm{FAR}=\mathrm{k})=\left(\lambda^{\mathrm{k}} / \mathrm{k} !\right) e^{-\lambda}
$$

where FAR is the financial asset range, representing financial capability and $\lambda=E(F A R)$. Denoting households by $i$, we estimate the following Poisson regression model:

$$
\log \left[\lambda\left(Y_{i}\right)\right]=X_{i} B+Z_{i} \Gamma+\mu_{i}
$$

where $Y_{i}$ is the financial asset range, $X_{i}$ is a vector of focused independent variables including employment type and household registration status, $Z_{i}$ is a vector of control variables and $\mu_{\mathrm{i}}$ is the error term.

Seven models were used in the analyses. Model I, II, and III used bivariate and multiple OLS regressions for key variable analyses, Model IV and VI used multiple OLS regressions by adding control variables, and Model V and VII used Poisson regressions. Model specifications are as follows:

$$
\begin{array}{ll}
\text { Model I: } & \mathrm{Y}_{\mathrm{i}}=\beta_{1} \mathrm{x}_{1 \mathrm{i}}+\mu_{1 \mathrm{i}} \\
\text { Model II: } & \mathrm{Y}_{\mathrm{i}}=\beta_{2} \mathrm{x}_{2 \mathrm{i}}+\mu_{2 \mathrm{i}} \\
\text { Model III: } & \mathrm{Y}_{\mathrm{i}}=\beta_{3} \mathrm{x}_{3 \mathrm{i}}+\beta_{4} \mathrm{x}_{4 \mathrm{i}}+\beta_{5} \mathrm{x}_{5 \mathrm{i}}+\mu_{3 \mathrm{i}} \\
\text { Model IV: } & \mathrm{Y}_{\mathrm{i}}=\mathrm{X}_{1 \mathrm{i}} \mathrm{B}_{1}+\mathrm{Z}_{\mathrm{i}} \Gamma_{1}+\mu_{4 \mathrm{i}} \\
\text { Model V: } & \log \left[\lambda\left(\mathrm{Y}_{\mathrm{i}}\right)\right]=\mathrm{X}_{1 \mathrm{i}} \mathrm{B}_{2}+\mathrm{Z}_{\mathrm{i}} \Gamma_{2}+\mu_{5 \mathrm{i}} \\
\text { Model VI: } & \mathrm{Y}_{\mathrm{i}}=\mathrm{X}_{2 \mathrm{i}} \mathrm{B}_{3}+\mathrm{Z}_{\mathrm{i}} \Gamma_{3}+\mu_{6 \mathrm{i}} \\
\text { Model VII: } & \log \left[\lambda\left(\mathrm{Y}_{\mathrm{i}}\right)\right]=\mathrm{X}_{2 \mathrm{i}} \mathrm{B}_{4}+\mathrm{Z}_{\mathrm{i}} \Gamma_{4}+\mu_{7 \mathrm{i}}
\end{array}
$$


where $Y_{i}$ is the financial asset range; $x_{1 i}$ is the indicator of employee in the system; $x_{2 i}$ is the indicator of rural household registration; $\mathrm{x}_{3 \mathrm{i}}, \mathrm{x}_{4 \mathrm{i}}$ and $\mathrm{x}_{5 \mathrm{i}}$ are the indicators of local rural, non-local urban and non-local rural household residence registration respectively; $\mathrm{X}_{1 i}$ is a vector of employee in the system and rural household registration; $\mathrm{X}_{2 i}$ is a vector of employee in the system, local rural, non-local urban and non-local rural household residence registration; $Z_{i}$ is a vector of control variables and $\mu_{\mathrm{ki}}(k=$ $1,2,3,4,5,6,7)$ is the error term.

\section{Results}

\subsection{Descriptive Statistics}

Table 2 presents descriptive statistics of financial asset holdings in the sample. As can be seen, only $63 \%$ of households had at least one financial asset, $57 \%$ of households had demand deposits and $18 \%$ of households had time deposits. Stock market participation was merely $9 \%$ while $4 \%$ of household bought mutual funds. Compared to the U.S. where $35 \%$ of general population had stocks, bonds, mutual funds or other securities (FINRAIEF, 2012), the financial market participation in China was low.

$$
\text { [Insert Table } 2 \text { here] }
$$

Table 3 presents descriptive statistics of the financial asset range. $37 \%$ of households had no financial assets at all. Most people (42\%) had only one type of financial asset. Only one household had seven types of financial assets and no household had more than seven types.

[Insert Table 3 here]

As shown in Table 4, $11 \%$ of respondents were employees in the government- 
managed working system, among which many worked in public service institution and state-owned enterprises. A little over half of the households were registered in rural area and less than $5 \%$ of households had non-local residence registration in either rural or urban area.

[Insert Table 4 here]

Table 5 reports descriptive statistics of control variables. The average age of the household heads was 50 . As for education, $92 \%$ of household heads did not have an undergraduate degree meaning that the average education level of Chinese people was still low. Approximately $74 \%$ of household heads in Chinese families were male. Data showed that $90 \%$ of families owned their home. Only $14 \%$ of household heads used credit cards. $61 \%$ of the household heads interviewed were in the low risk preference group.

[Insert Table 5 here]

\subsection{Results of Regression Analysis}

In Table 6, we found in bivariate analysis (Model I), the coefficient of employment in the system variable was significantly positive. In Model II, people with rural registration had a significantly smaller financial asset range. In Model III, people with non-local registration had a significantly larger financial asset range compared to people with local registration in both urban and rural group. In both local and non-local groups, people with rural registration had significantly smaller financial asset ranges, which confirmed the result of Model II.

[Insert Table 6 here]

Table 7 presents results of multiple regressions by adding control variables. The 
results were as expected. In all four models, the effect of employment in the system on the household financial asset range was significantly positive. Results of two sets of OLS regressions were similar. The findings suggested that people employed in the government-managed system had better financial capability than those employed in collective and private owned enterprises, supporting $\mathrm{H} 1$.

[Insert Table 7 here]

Results of both Models IV and V showed that the rural household residence registration was negatively associated with the household financial asset range, suggesting people with rural household residence registration had lower financial capability compared to their urban counterparts and supporting $\mathrm{H} 2$.

Results regarding $\mathrm{H} 3$ are interesting. After adding control variables in Models VI and VII, the coefficients of non-local urban household residence registration became negative and not significant, while in Model III it was significantly positive without control variable. We speculate the result of Model III may be resulted from the higher education level of people with non-local urban registration compared to those with local urban registration. With this data set, we translated the education into years of schooling according to China's education system, and found that on average, people with local urban registration had 9.6 years of school while people with non-local urban registration had 13.2 years of school. After controlling for education, the advantage of people with non-local urban registration in terms of financial capability became insignificant. In either case, H3 was not supported.

In model VII, both coefficients of local and non-local rural registrations were significantly negative and the coefficient of non-local rural registration was smaller than 
local rural registration, suggesting people with non-local rural registration had better financial capability and supporting $\mathrm{H} 4$. To provide a more direct test, we conducted an additional analysis similar to model VII with one change, using the local rural people as the reference group, and found that the coefficient of non-local rural group was significantly positive (The table is not presented here but available upon requests).

Some control variables provided signs consistent with our expectations. Age, having undergraduate or higher degree, net household asset, marriage, being a financial service worker, owning a home, having a credit card, being in higher preference of risk group and preferring future consumption than present all had positive effects on the financial asset range. However in our study, gender was not significant. Since net household income was significantly positively correlated with household asset, when household asset entered into the regression with household income, household income lost its significance. Owning a business was positively associated with the dependent variable in all four models but not significant in OLS regressions. Geographically, people in the east region had larger average financial asset ranges, followed by people in the central region and west region. It was consistent with our understanding that the east of China is the most economically developed area, as the average annual income per capita of urban households in the east is about $50 \%$ higher than that in the central and west (Xu and Kong, 2015). What is shocking is that people in the northeast region had the lowest average financial asset range, even lower than people in the central and west. It reflected the common belief that the northeast region, the former industrial power house, was a rustbelt today and needs to be revitalized. 


\subsection{Robustness Checks}

To ensure the robustness of our results to alternative measures and methods, we performed several additional tests, the results of which can be found in the Table 8. First, we used the ratio of financially risky asset to total financial asset as a second alternative dependent variable and conducted the Tobit regression, given that the financially risky asset ratio lied within the range between 0 and 1 . Financially risky assets were measured by total market value of financial asset excluding demand deposit, time deposit, state bond and local government bond. By using financially risky asset, we placed more emphasis on the risky assets since investment in risky assets requires more comprehensive financial knowledge. In the construction of the second alternative dependent variable, we added a dummy variable indicating whether a household had a non-primary housing to the financial asset range, since the non-primary housing is usually considered as an investment and the purchase of property requires some degree of financial capability. We generated a third alternative dependent variable by adding a dummy variable indicating whether a household had its own business. Thus, we accounted for the roles of owning a home and a business in the computation of financial capabilities. The main results of Model VIII to Model XIII were qualitatively consistent with those in Table 7.

In addition, we constructed the weighted financial asset to account for the roles of different riskiness of each financial asset and its share in the portfolio. The accurate calculation was difficult because the data of exact risks of the nine financial asset instruments were not available. Thus we used the variance of the monthly return rate of 
each financial asset in 2011 as proxies for the risk of each financial asset. The annual interest rates of demand deposit and one-year time deposit published by the People's Bank of China were used to generate the monthly interest rate for demand deposit and time deposit. We used the monthly average of the CSI 300 Index, a capitalization-weighted stock market index designed to replicate the performance of 300 stocks traded in the Shanghai and Shenzhen Stock Exchanges, to represent the market performance of the stocks in general; the monthly average of the Shanghai Stock Exchange treasure index settlement price to represent the market performance of the bonds in general; the monthly average of Shanghai Stock Exchange funds index settlement price to represent the market performance of the mutual funds in general; the Shanghai Stock Exchange financial futures monthly settlement price to represent the market performance of the derivatives in general; the monthly average of the price of the US dollar in RMB published by the People's Bank of China to represent the market performance of the non RMB denominated assets in general; the monthly average gold price in RMB published by the World Gold Council to represent the market performance of the gold. With the monthly market performance of these six financial assets, we generated the monthly return rate by the following equation:

$$
\mathrm{MRR}_{i, t}=\left(\mathrm{MP}_{i, t}-\mathrm{MP}_{i, t-1}\right) / \mathrm{MP}_{i, t-1}
$$

where $\mathrm{MRR}_{i, t}$ is the monthly return rate of asset $i$ in month $t$ and $\mathrm{MP}_{i, t}$ is the market performance of asset $i$ in month $t$. The monthly return rate is comparable to the monthly interest rates of demand deposit and time deposit. We then computed the variance of the monthly return rate of each financial asset and generated weights for each 
financial asset using the following equation:

$$
\omega_{i}=\sigma_{\mathrm{i}}^{2} / \sum \sigma_{\mathrm{i}}^{2}
$$

where $\omega_{i}$ is the weight for the financial asset $i$ and $\sigma_{i}^{2}$ is the variance of the monthly return rate of financial asset $i$. Therefore the weighted financial asset was constructed by:

$$
W F A=\sum \omega_{i} \mathrm{MV}_{i}
$$

where $W F A$ is the weighted financial asset and $\mathrm{MV}_{i}$ is the market value of the financial asset $i$. Since we could not find any data for the wealth management product, following our understanding that the riskiness of a wealth management product lies between time deposit and bonds, we used the average variance of time deposit and bonds to proxy the variance of wealth management product and generate its weight accordingly. We removed total household net asset because the weighted financial asset measured the financial asset of the household, which was a substantial part of total household net asset. The patterns of Model XIV and Model XV were the similar to the results of baseline regressions.

Second, we conducted the negative binomial regression, given the nature of the financial asset range measure. Negative binomial model and Poisson model are normally adopted for the analyses of discrete choice dependent variables. Negative binomial model relaxes the Poisson assumption that the mean equals the variance (Greene, 2012). Though the deviance goodness-of-fit tests and Pearson goodness-of-fit tests showed that there was no over-dispersion and Poisson regression was appropriate, we used negative binomial regression as robustness checks for Poisson regression results. The results of 
Model XVI and Model XVII in Table 8 were largely consistent with our Poisson analyses in Table 7. The results of robustness checks are presented in the Table 8.

\section{Conclusions}

In this paper we examine the factors associated with Chinese consumer financial capability measured by the household financial asset range from the perspective of background risks with emphases on two independent variables with unique Chinese features, employment type and household residential registration status. We have achieved our research objectives that are to explore if there are differences in financial capability between people working in two different types of working systems and between people with different household residency registrations. We find employees in the government-managed working system and people having urban residence registration have better financial capability. Among people with rural residence registrations, nonlocal people have better financial capability. Consumer with young age, having low income, without undergraduate or higher degree, not using a credit card, working in non-financial service occupations and living in the northeast region tend to have a lower level of financial capability.

The limitation of this study is that we do not investigate mechanisms between the two focused independent variables and financial capability because it can be complicated and beyond the scope of this paper. In addition, some control variables such as owning a business and gender show results different from previous research using data of developed countries. These issues could be addressed in future research.

The results of this study are informative for helping consumer financial educators to 
identify vulnerable consumers in the financial market. Understanding the employment type and residence registration differences in financial capability helps financial educators provide pertinent education to Chinese consumers with diverse needs. Consumer educators should be aware of differences in financial literacy, behavior, and capability among consumers with diverse backgrounds. To increase effectiveness in financial education, financial educators should provide tailored education for vulnerable consumers with low income and low education, not using a credit card, working in nonfinancial service occupations and private sectors, and living in the rural areas and less developed regions in China. If possible, basic financial education should be provided in junior high or high school as most people do not go to college. 


\section{Acknowledgement}

The China Scholarship Council provided the support for Mr. Xu Cui, a doctoral student

from School of Busniess, Renmin University of China, for his research as a visiting scholar at the University of Rhode Island with a scholarship (grant number [2016]3100). We thank Deborah Kopech for her assistance in copy editing. 


\section{References}

Abreu, M. and V. Mendes (2010). Financial Literacy and Portfolio Diversification. Quantitative Finance, 10(5), 515-528.

Afridi, F., Li, S. X., and Y. Ren (2015). Social Identity and Inequality: The Impact of China's Hukou System. Journal of Public Economics, 123, 17-29.

Atkinson, A., McKay, S., Collard, S. and E. Kempson (2006). Levels of Financial Capability in the UK: Results of a Baseline Survey. Financial Services Authority, London.

Bai, C. E., Lu, J. and Z. Tao (2009). How Does Privatization Work in China? Journal of Comparative Economics, 37(3), 453-470.

Brødsgaard, K. E. (2002). Institutional Reform and the Bianzhi System in China. The China Quarterly, 170, 361-386.

Cai, Y. and Y. Cheng (2014). Pension Reform in China: Challenges and Opportunities. Journal of Economic Surveys, 28(4), 636-651.

Cardak, B. A. and R. Wilkins (2009). The Determinants of Household Risky Asset Holdings: Australian Evidence on Background Risk and Other Factors. Journal of Banking and Finance, 33(5), 850-860.

Chan, K. W. (2010). The Household Registration System and Migrant Labor in China: Notes on a Debate. Population and Development Review, 36(2), 357-364.

Chan, K. W. and Buckingham, W. (2008). Is China Abolishing the Hukou System?. The China Quarterly, 195, 582-606.

Chinanews. 2016 Oct 24. The 2017 Annual National Examination Application Ended with the Admission Rate of the Hottest Post Being "One in Ten Thousand". Retrieved 
from http://www.chinanews.com/gn/2016/10-24/8042039.shtml

Cheng, T., and M, Selden. (1994). The Origins and Social Consequences of China's Hukou System. The China Quarterly, 139, 644-668.

Cui, F., Ge, Y. and F. Jing (2013). The Effects of the Labor Contract Law on the Chinese Labor Market. Journal of Empirical Legal Studies, 10(3), 462-483.

Cui, Y., Nahm, D., and M. Tani (2015). Employment Choice and Ownership Structure in Transitional China. The Singapore Economic Review, Vol. 60, No. 4 ,1550088. DOI: $10.1142 / \mathrm{S} 0217590815500885$

Deidda, M. (2014). Does Portfolio Diversification Mitigate Financial Risk? Evidence from Italian Survey Data. Rivista Italiana Degli Economisti, 19(3), 393-420.

Du, J. (2009). Economic Reforms and Health Insurance in China. Social Science \& Medicine, 69(3), 387-395.

Fang, Z., and Sakellariou, C. (2016). Social Insurance, Income and Subjective Well-Being of Rural Migrants in China-An Application of Unconditional Quantile Regression. Journal of Happiness Studies, 17(4), 1635-1657.

FINRAIEF. (2013) Financial capability in the United States: Report of findings from the 2012 National Financial Capability Study. FINRA Investor Education Foundation, Washington, DC.

Fu, J. (2014). To Start a Business or to Pursue for a "Bianzhi"? Empirical Analysis of Income Differences Between Self-employers and Officials. Shanghai Economic Review. (6), 93-102.

Gan, L. Yin, Z. H. Jia, N. Xu, S.and S. Ma (2013). Data You Need to Know about China. 
Springer.

Gao, Q., Ying, Q. and D. Luo (2015). Hidden Income and Occupational Background: Evidence from Guangzhou. Journal of Contemporary China, 24(94), 721-741.

Georgarakos, D. and R. Inderst (2011). Financial Advice and Stock Market Participation. European Central Bank, Working Paper Series: 1296.

Greene, William H. (2012). Econometric Analysis (Seventh Edition). New Jersey: PrenticeHall.

Guiso, L. and T. Jappelli (2008) Financial Literacy and Portfolio Diversification. CSEF Working Papers 212, Centre for Studies in Economics and Finance, Naples (Italy).

Haliassos, M. and C.C. Bertaut (1995). Why Do so Few Hold Stocks? Economic Journal, 105, $1110-1129$.

Han, L., Chen, H. S. and C. G. Liu (2016) Is There Intergeneration Transmission of the "Iron Rice Bowl"? Empirical Analysis of Chinese Bianzhi Job Post. Economic Perspectives, (8), 61-70.

He, L. X., Wu, H. J. and Z. G. Zhang (2015). Analysis on the Income Difference between Non-local Migrant Workers and Local Migrant Workers -- Based on the Perspective of Household Registration. Journal of Agrotechnical Economics, (6), 15-26.

Heaton, J. and D. Lucas (2000). Portfolio Choice and Asset Prices: The Importance of Entrepreneurial Risk. Journal of Finance, 55(3), 1163-1198.

Hochguertel, S. (2003). Precautionary Motives and Portfolio Decisions. Journal of Applied Econometrics, 18, 61-77.

Jappelli, T. and M. Padula (2015). Investment in Financial Literacy, Social Security and 
Portfolio Choice. Journal of Pension Economics and Finance, 14(4), 369-411.

Li, P. and F. Tian (2011). New generation of farmer workers in China: Social attitude and behavior choice. Society, 31(3), $1-21$.

Lin, J. T., Bumcrot, C., Ulicny, T., Lusardi, A., Mottola, G., Kieffer, C. and G. Walsh (2016). Financial Capability in the United States: Report of Findings from the 2015 National Financial Capability Study. FINRA Investor Education Foundation, Washington, DC. Retrieved from http://gflec.org/wpcontent/uploads/2016/07/NFCS_2015_Report_Natl_Findings.pdf

Lusardi, A., and O. S. Mitchell (2011). Financial Literacy and Retirement Planning in the United States. Journal of Pension Economics and Finance, 10(4), 509-525.

Lusardi, A., and O. S. Mitchell (2014). The Economic Importance of Financial Literacy: Theory and Evidence. Journal of Economic Literature, 52(1), 5-44.

Markowitz, H. (1952). Portfolio Selection. The Journal of Finance, 7(1), 77-91.

National Bureau of Statistics of China. (2016). China Statistical Yearbook-2016. Retrieved from http://www.stats.gov.cn/tjsj/ndsj/2016/indexeh.htm

National People's Congress of the People's Republic of China. (1958). The ordinance of household registration of the People's Republic of China (Zhong Hua Ren Min Gong He Guo Hu Kou Deng Ji Tiao Li). Promulgated at the nighty-first Session of the Standing Committee of the National People's Congress on January $9^{\text {th }}, 1958$. Retrieved from http://www.npc.gov.cn/wxzl/gongbao/200012/10/content_5004332.htm.

OECD. (2016). Financial Education in Europe: Trends and Recent Developments. OECD 
Publishing, Paris.

Robb, C. A., and A. S. Woodyard (2011). Financial Knowledge and Best Practice Behavior. Journal of Financial Counseling and Planning, 22(1), 60-70, 86-87.

Rosen, H.S. and S. Wu (2004). Portfolio Choice and Health Status. Journal of Financial Economics, 72, 457-484.

Shi, S. J. and K. H. Mok (2012). Pension Privatisation in Greater China: Institutional Patterns and Policy Outcomes. International Journal of Social Welfare, 21(s1), S30-S45.

Sonoda, T. (2014). Why Do Household Heads In Rural China Not Work More In The Market? The Singapore Economic Review, 59(01), 1450008. DOI: $10.1142 / \mathrm{S} 0217590814500088$

StataCorp. (2013). Stata 13 Base Reference Manual. College Station, TX: Stata Press. 1640. Taylor, M. (2011). Measuring Financial Capability and Its Determinants Using Survey Data. Social Indicators Research, 102, 297-314.

The Peoples' Bank of China. (2013, August 27). The Peoples' Bank of China Promotes Financial Literacy Month Program. Retrieved from http://www.gov.cn/gzdt/201308/27/content_2474944.htm

Tsigos, S., \& Daly, K. (2016). "Fair go" for all? Wealth and Risk Aversion of Australian Households. Australian Economic Papers, 55(3), 274-300.

Van Rooij, M., Lusardi, A., and R. Alessie (2011). Financial Literacy and Stock Market Participation. Journal of Financial Economics, 101(2), 449-472.

Wang, Y. J., Liu, Y. L., Li, Z. B., Xing, C. B., Cui, X. Y. and C. Jiang (2016). Household Registration and College Students' Employment: An Empirical Research Based on 
Sampling Survey Data of Employment Situation of College Graduates. Studies in Labor Economics, (2), 72-94.

Wong, K., Fu, D., Li, C. Y., and H. X. Song (2007). Rural Migrant Workers in Urban China: Living a Marginalised Life. International Journal of Social Welfare, 16(1), 32-40.

Wu, W. (2006). Migrant Intra-urban Residential Mobility in Urban China. Housing Studies, 21(5), 745-765.

Xiao, J. J., Chen, C. and F. Chen (2014). Consumer Financial Capability and Financial Satisfaction. Social Indicators Research, 118(1), 415-432.

Xiao, J. J., Chen, C. and L. Sun (2015). Age differences in consumer financial capability. International Journal of Consumer Studies, 39, 387-395.

Xie, G. H. (2012). Human Capital Return and Social Integration of Migrant Population in China. Social Sciences in China, 04, 103-124.

Xu, J. and D. Kong (2015). Understanding the Household Consumption Behavior in Urban China. The Singapore Economic Review, 60(05), 1550062. DOI:

$10.1142 / \mathrm{S} 0217590815500629$

Yin, Z. C., Song, Q. Y. and Y. Wu (2014). Financial Literacy, Trading Experience and Household Portfolio Choice. Economic Research, 04, 62-75.

Zhang, M. and R. Rasiah, (2014). Institutional Change and State Owned Enterprises in China's Urban Housing Market. Habitat International, 41, 58-68.

Zhang, Y., Filipski, M. J., and K. Z. Chen (2016). Health Insurance and Medical Impoverishment in Rural China: Evidence from Guizhou Province. The Singapore Economic Review, Vol. 62, No. 1, 1650017. DOI: 10.1142/S021759081650017X 
Zhang, Z., and D. J. Treiman (2013). Social Origins, Hukou Conversion, and the Wellbeing of Urban Residents in Contemporary China. Social Science Research, 42(1), 71-89.

Zhu, L. (2003). The hukou system of the People's Republic of China: a critical appraisal under International Standards of Internal Movement and Residence. Chinese Journal of International Law, 2(2), 519-566. 
Table 1 Variable Specifications

\begin{tabular}{|c|c|}
\hline Dependent Variable & $\begin{array}{l}\text { Attribute } \\
\end{array}$ \\
\hline Financial asset range & $\begin{array}{l}\text { 0-9, the sum of dummy variables of demand deposits, time } \\
\text { deposits, stocks, bonds, mutual funds, derivatives, wealth } \\
\text { management products, non RMB denominated assets and } \\
\text { gold. For each dummy, } 1 \text { - Own, 0 - Not own. }\end{array}$ \\
\hline Independent Variables & \begin{tabular}{|c|} 
Attribute \\
\end{tabular} \\
\hline Employment in the system & $\begin{array}{l}\text { People working in civil service, in military, in public institutions } \\
\text { and in state-owned enterprises. } 1-\text { Yes, } 0-\text { No }\end{array}$ \\
\hline Rural residence registration & $1-$ Yes, $0-$ No \\
\hline Local urban residence registration & $1-$ Yes, $0-$ No \\
\hline Local rural residence registration & $1-$ Yes, $0-$ No \\
\hline $\begin{array}{l}\text { Non-local urban } \quad \text { residence } \\
\text { registration }\end{array}$ & $1-$ Yes, $0-$ No \\
\hline $\begin{array}{l}\text { Non-local rural } \quad \text { residence } \\
\text { registration }\end{array}$ & $1-$ Yes, $0-$ No \\
\hline Control Variables & Attribute \\
\hline Age & Year (17 or above) \\
\hline Undergraduate degree or higher. & $1-$ Yes, $0-$ No \\
\hline Net household income & $\begin{array}{l}\text { The sum of each family member's last year after tax wage, after } \\
\text { tax bonus, after-tax subsidies or subsidy in-kind and money } \\
\text { obtained from the second job plus net profit earned from } \\
\text { agriculture project, net profit earned from private business } \\
\text { project, rent earned from land lease, rent earned from house } \\
\text { lease and rent earned from car lease. }\end{array}$ \\
\hline Total household net asset & $\begin{array}{l}\text { The sum of financial asset and nonfinancial asset. Nonfinancial } \\
\text { asset is the market value of agricultural product and tools, } \\
\text { the share of business project, homes, vehicles and other } \\
\text { assets minus outstanding bank loans, home mortgages, } \\
\text { vehicle mortgage and any other of debts. }\end{array}$ \\
\hline Male & $1-$ Yes, $0-$ No \\
\hline Married & $1-$ Yes, $0-$ No \\
\hline Financial service worker & $1-$ Yes, $0-$ No \\
\hline Owning a business & $1-$ Yes, $0-$ No \\
\hline Homeowner & $1-$ Yes, $0-$ No \\
\hline Having a credit card & $1-Y e s, 0-$ No \\
\hline Family size & Number of people in household \\
\hline Rural & $1-$ Yes, $0-$ No \\
\hline Region & $\begin{array}{l}\text { Dummy variables representing west region, central region, east } \\
\text { region, and northeast region. }\end{array}$ \\
\hline Risk attitude & $\begin{array}{l}\text { When asked "Assume you have some assets to invest, which type } \\
\text { of project would you invest in?" those who choose "High } \\
\text { Risk, High Return" and "Slightly above-average risk, slightly } \\
\text { above-average return" are grouped into high risk preference } \\
\text { group. Those who choose "Average risk, average return } \\
\text { projects" are grouped into moderate risk preference group. } \\
\text { Those who choose "Slightly below-average risk, slightly } \\
\text { below-average return" and "Unwilling to take any risk" are } \\
\text { grouped into low risk preference group. One group dummy } \\
\text { is generated for each group. }\end{array}$ \\
\hline $\begin{array}{l}\text { Prefer future consumption to } \\
\text { present }\end{array}$ & $\begin{array}{l}\text { Based on the survey question "The word of question: Assume that } \\
\text { the current interest rate is zero and there is no price inflation }\end{array}$ \\
\hline
\end{tabular}


to be factored in, which of the following payments would you prefer, 1000 RMB on tomorrow or 1100 RMB in one year?" 1- Get 1100 a year from now, 0 - Get 1000 RMB tomorrow 
Table 2 Details of Financial Asset Holdings $(\mathrm{N}=8,016)$

\begin{tabular}{lccc}
\hline Types of Financial Asset & Frequency & Percent & Std. Dev. \\
\hline Demand deposits & 4546 & $56.71 \%$ & 0.50 \\
Time deposits & 1443 & $18.00 \%$ & 0.38 \\
Stocks & 722 & $9.01 \%$ & 0.29 \\
Bonds & 63 & $0.79 \%$ & 0.09 \\
Mutual funds & 346 & $4.32 \%$ & 0.20 \\
Derivatives & 4 & $0.05 \%$ & 0.02 \\
Wealth management products & 67 & $0.84 \%$ & 0.09 \\
Non RMB denominated assets & 88 & $1.10 \%$ & 0.10 \\
Gold & 52 & $0.65 \%$ & 0.08 \\
Holding any of above & 5039 & $62.86 \%$ & - \\
\hline
\end{tabular}


Table 3 Details of Financial Asset Range

\begin{tabular}{lccccccccc}
\hline Count Variable & \multicolumn{10}{c}{ Financial asset range } \\
\hline Value & $\mathbf{0}$ & $\mathbf{1}$ & $\mathbf{2}$ & $\mathbf{3}$ & $\mathbf{4}$ & $\mathbf{5}$ & $\mathbf{6}$ & $\mathbf{7}$ & Total \\
Frequency & 2,977 & 3,360 & 1,236 & 324 & 82 & 24 & 12 & 1 & 8016 \\
Percent & $37.14 \%$ & $41.92 \%$ & $15.42 \%$ & $4.04 \%$ & $1.02 \%$ & $0.30 \%$ & $0.15 \%$ & $0.01 \%$ & $100.00 \%$ \\
\hline
\end{tabular}


Table 4 Descriptive Statistics of Employment Type and Household Registration Status

\begin{tabular}{ccc}
\hline & Frequency & Percentage \\
\hline Employees in the system & 900 & $11.23 \%$ \\
Fiscally dependent employees & 555 & $6.92 \%$ \\
In government & 141 & $1.76 \%$ \\
In public service institution & 409 & $5.10 \%$ \\
In military & 5 & $0.06 \%$ \\
In state-owned enterprises & 392 & $4.89 \%$ \\
Employees not in the system & 7116 & $88.77 \%$ \\
Urban household residence registration & 3810 & \\
Local urban registration & 3581 & $47.53 \%$ \\
Non-local urban registration & 229 & $44.67 \%$ \\
Rural household residence registration & 4206 & $2.86 \%$ \\
Local rural registration & 3844 & $52.47 \%$ \\
Non-local rural registration & 362 & $47.95 \%$ \\
\hline
\end{tabular}




\section{Table 5 Descriptive Statistics ( $=8016$ )}

\begin{tabular}{lcc}
\hline & Mean & Std. Dev. \\
\hline Age & 49.84 & 13.99 \\
Net household income (yuan) & 26121.21 & 142319.00 \\
Total household net asset (yuan) & 466122.70 & 959908.90 \\
Family size & 3.48 & 1.54 \\
\hline & Frequency & Percentage \\
\hline Undergraduate degree or higher & 649 & $8.10 \%$ \\
Male & 5875 & $73.29 \%$ \\
Married & 7001 & $87.34 \%$ \\
Financial service worker & 224 & $2.79 \%$ \\
Owning a business & 1020 & $12.72 \%$ \\
Homeowner & 7291 & $90.96 \%$ \\
Having a credit card & 1132 & $14.12 \%$ \\
Rural & 3072 & $38.32 \%$ \\
In west region & 1184 & $14.77 \%$ \\
In central region & 2412 & $30.09 \%$ \\
In east region & 3418 & $42.64 \%$ \\
In northeast region & 1002 & $12.50 \%$ \\
In low risk preference group & 4869 & $60.74 \%$ \\
In moderate risk preference group & 2069 & $25.81 \%$ \\
In high risk preference group & 1078 & $13.45 \%$ \\
Prefer future consumption to present & 2352 & $29.34 \%$ \\
\hline
\end{tabular}




\section{Table 6 Key Variable OLS Analysis of Household Financial Asset Range}

\begin{tabular}{lccc}
\hline Variable & $\begin{array}{c}\text { Model I } \\
\text { OLS }\end{array}$ & $\begin{array}{c}\text { Model II } \\
\text { OLS }\end{array}$ & $\begin{array}{c}\text { Model III } \\
\text { OLS }\end{array}$ \\
\hline Employees in the system & $0.633^{* * *}$ & - & - \\
Rural household residence registration & $(0.032)$ & - & - \\
& - & $-0.611^{* * *}$ & - \\
Local urban household residence registration (reference category) & - & $(0.020)$ & - \\
- & - & - & - \\
Local rural household residence registration & - & - & $-0.629^{* * *}$ \\
Non-local urban household residence registration & - & - & $(0.020)$ \\
& - & - & $0.163^{* * *}$ \\
Non-local rural household residence registration & - & - & $(0.060)$ \\
& - & - & $-0.311^{* * *}$ \\
Constant & - & - & $(0.048)$ \\
& $0.843^{* * *}$ & $1.235^{* * *}$ & $1.225^{* * *}$ \\
Observations & $(0.011)$ & $(0.014)$ & $(0.015)$ \\
R-squared & 8,016 & 8,016 & 8,016 \\
\hline
\end{tabular}

Standard errors in parentheses

$* * * p<0.01, * * p<0.05, * p<0.1$ 


\section{Table 7 Results of Regressions on Household Financial Asset Range}

\begin{tabular}{|c|c|c|c|c|}
\hline Variable & Model IV & Model V & Model VI & $\begin{array}{c}\text { Model } \\
\text { VII } \\
\text { Poisson }\end{array}$ \\
\hline Employees in the system & $\begin{array}{c}0.160 * * * \\
(0.032)\end{array}$ & $\begin{array}{c}0.129 * * * \\
(0.035)\end{array}$ & $\begin{array}{c}0.160 * * * \\
(0.033)\end{array}$ & $\begin{array}{c}0.129 * * * \\
(0.035)\end{array}$ \\
\hline Rural household residence registration & $\begin{array}{c}- \\
0.302 * * * \\
(0.024)\end{array}$ & $\begin{array}{c}- \\
0.367^{* * *} \\
(0.032)\end{array}$ & & \\
\hline \multicolumn{5}{|c|}{$\begin{array}{l}\text { Local urban household residence registration (reference } \\
\text { category) }\end{array}$} \\
\hline Local rural household residence registration & & & $\begin{array}{c}- \\
0.321^{* * *} \\
(0.026)\end{array}$ & $\begin{array}{c}- \\
0.403 * * * \\
(0.035)\end{array}$ \\
\hline Non-local urban household residence registration & & & $\begin{array}{l}-0.007 \\
(0.056)\end{array}$ & $\begin{array}{l}-0.008 \\
(0.060)\end{array}$ \\
\hline Non-local rural household residence registration & & & $\begin{array}{c}- \\
0.205^{* * *} \\
(0.047)\end{array}$ & $\begin{array}{c}- \\
0.218^{* * *} \\
(0.061)\end{array}$ \\
\hline Age & $\begin{array}{c}0.000 \\
(0.001)\end{array}$ & $\begin{array}{c}0.000 \\
(0.001)\end{array}$ & $\begin{array}{c}0.001 \\
(0.001)\end{array}$ & $\begin{array}{c}0.001 \\
(0.001)\end{array}$ \\
\hline Undergraduate degree or higher & $\begin{array}{c}0.226 * * * \\
(0.038)\end{array}$ & $\begin{array}{c}0.126 * * * \\
(0.039)\end{array}$ & $\begin{array}{c}0.231 * * * \\
(0.038)\end{array}$ & $\begin{array}{c}0.132 * * * \\
(0.039)\end{array}$ \\
\hline Net household income & $\begin{array}{c}0.000 \\
(0.000)\end{array}$ & $\begin{array}{c}0.000 \\
(0.000)\end{array}$ & $\begin{array}{c}0.000 \\
(0.000)\end{array}$ & $\begin{array}{c}0.000 \\
(0.000)\end{array}$ \\
\hline Total household net asset & $\begin{array}{c}0.000 * * * \\
(0.000)\end{array}$ & $\begin{array}{c}0.000 * * * \\
(0.000)\end{array}$ & $\begin{array}{c}0.000 * * * \\
(0.000)\end{array}$ & $\begin{array}{c}0.000 * * * \\
(0.000)\end{array}$ \\
\hline Male & $\begin{array}{c}0.031 \\
(0.021)\end{array}$ & $\begin{array}{c}0.036 \\
(0.027)\end{array}$ & $\begin{array}{c}0.032 \\
(0.021)\end{array}$ & $\begin{array}{c}0.038 \\
(0.027)\end{array}$ \\
\hline Married & $\begin{array}{c}0.123 * * * \\
(0.029)\end{array}$ & $\begin{array}{c}0.135 * * * \\
(0.039)\end{array}$ & $\begin{array}{c}0.124 * * * \\
(0.029)\end{array}$ & $\begin{array}{c}0.136 * * * \\
(0.039)\end{array}$ \\
\hline Family size & $\begin{array}{c}-0.016 * * \\
(0.007)\end{array}$ & $\begin{array}{c}-0.019 * * \\
(0.009)\end{array}$ & $\begin{array}{c}-0.015^{* *} \\
(0.007)\end{array}$ & $\begin{array}{c}-0.017^{*} \\
(0.009)\end{array}$ \\
\hline Financial service worker & $\begin{array}{c}0.254 * * * \\
(0.056)\end{array}$ & $\begin{array}{c}0.160 * * * \\
(0.055)\end{array}$ & $\begin{array}{c}0.255^{* * *} \\
(0.056)\end{array}$ & $\begin{array}{c}0.161 * * * \\
(0.055)\end{array}$ \\
\hline Owning a business & $\begin{array}{l}-0.019 \\
(0.028)\end{array}$ & $\begin{array}{c}0.012 \\
(0.036)\end{array}$ & $\begin{array}{c}-0.020 \\
(0.028)\end{array}$ & $\begin{array}{c}0.009 \\
(0.036)\end{array}$ \\
\hline Homeowner & $\begin{array}{c}0.055^{*} \\
(0.033)\end{array}$ & $\begin{array}{c}0.086 * * \\
(0.043)\end{array}$ & $\begin{array}{c}0.063 * \\
(0.033)\end{array}$ & $\begin{array}{c}0.097 * * \\
(0.044)\end{array}$ \\
\hline Credit card & $\begin{array}{c}0.380 * * * \\
(0.030)\end{array}$ & $\begin{array}{c}0.299 * * * \\
(0.033)\end{array}$ & $\begin{array}{c}0.381 * * * \\
(0.030)\end{array}$ & $\begin{array}{c}0.300 * * * \\
(0.033)\end{array}$ \\
\hline Rural & $\begin{array}{c}- \\
0.178 * * * \\
(0.024)\end{array}$ & $\begin{array}{c}- \\
0.281^{* * *} \\
(0.034)\end{array}$ & $\begin{array}{c}- \\
0.166^{* * *} \\
(0.025)\end{array}$ & $\begin{array}{c}- \\
0.260 * * * \\
(0.035)\end{array}$ \\
\hline \multicolumn{5}{|l|}{ In east region (reference category) } \\
\hline In west region & $\begin{array}{c}- \\
0.077^{* * *} \\
(0.029)\end{array}$ & $\begin{array}{c}- \\
0.128 * * * \\
(0.042)\end{array}$ & $\begin{array}{c}-0.072^{* *} \\
(0.029)\end{array}$ & $\begin{array}{c}- \\
0.120 * * * \\
(0.042)\end{array}$ \\
\hline In central region & $\begin{array}{l}-0.007 \\
(0.023)\end{array}$ & $\begin{array}{c}-0.032 \\
(0.030)\end{array}$ & $\begin{array}{c}-0.000 \\
(0.023)\end{array}$ & $\begin{array}{c}-0.024 \\
(0.030)\end{array}$ \\
\hline In northeast region & - & - & - & - \\
\hline
\end{tabular}




\begin{tabular}{lcccc} 
& $0.275^{* * *}$ & $0.342^{* * *}$ & $0.272^{* * *}$ & $0.338^{* * *}$ \\
& $(0.030)$ & $(0.042)$ & $(0.030)$ & $(0.042)$ \\
In low risk preference (reference category) & & & & \\
& & & & \\
In central risk preference & $0.110^{* * *}$ & $0.124^{* * *}$ & $0.110^{* * *}$ & $0.125^{* * *}$ \\
& $(0.022)$ & $(0.028)$ & $(0.022)$ & $(0.028)$ \\
In high risk preference & $0.142^{* * *}$ & $0.153^{* * *}$ & $0.142^{* * *}$ & $0.152^{* * *}$ \\
& $(0.028)$ & $(0.035)$ & $(0.028)$ & $(0.035)$ \\
Prefer future consumption to present & $0.045^{* *}$ & $0.056^{* *}$ & $0.045^{* *}$ & $0.057^{* *}$ \\
& $(0.020)$ & $(0.026)$ & $(0.020)$ & $(0.026)$ \\
Constant & $0.809^{* * *}$ & $-0.171^{* *}$ & $0.777^{* * *}$ & - \\
& & & & $0.215^{* * *}$ \\
& $(0.057)$ & $(0.075)$ & $(0.060)$ & $(0.078)$ \\
Observations & 8,016 & 8,016 & 8,016 & 8,016 \\
Adjusted $\mathrm{R}^{2}$ & 0.252 & - & 0.252 & - \\
Pseudo $\mathrm{R}^{2}$ & - & 0.084 & - & 0.085 \\
\hline
\end{tabular}

Standard errors in parentheses.

${ }^{* * *} p<0.01,{ }^{* *} p<0.05,{ }^{*} p<0.1$ 
Table 8 Robustness Checks

\begin{tabular}{|c|c|c|c|c|c|c|c|c|c|c|}
\hline Dependent Variable & $\begin{array}{l}\text { Model VIII } \\
\text { Risky Asset } \\
\text { Ratio }\end{array}$ & $\begin{array}{l}\text { Model IX } \\
\text { Risky Asset } \\
\text { Ratio }\end{array}$ & $\begin{array}{c}\text { Model X } \\
\text { Financial Asset } \\
\text { Range plus Non } \\
\text { Primary Home } \\
\end{array}$ & $\begin{array}{c}\text { Model XI } \\
\text { Financial Asset } \\
\text { Range plus Non } \\
\text { Primary Home } \\
\end{array}$ & $\begin{array}{c}\text { Model XII } \\
\text { Financial Asset Range } \\
\text { plus Non Primary } \\
\text { Home and Business } \\
\end{array}$ & $\begin{array}{c}\text { Model XIII } \\
\text { Financial Asset Range } \\
\text { plus Non Primary } \\
\text { Home and Business } \\
\end{array}$ & $\begin{array}{c}\text { Model XIV } \\
\text { Weighted } \\
\text { Financial Asset }\end{array}$ & $\begin{array}{c}\text { Model XV } \\
\text { Weighted } \\
\text { Financial Asset }\end{array}$ & $\begin{array}{l}\text { Model XVI } \\
\text { Financial } \\
\text { Asset Range }\end{array}$ & $\begin{array}{l}\text { Model XVII } \\
\text { Financial } \\
\text { Asset Range }\end{array}$ \\
\hline Independent Variables & Tobit & Tobit & Poisson & Poisson & Poisson & Poisson & OLS & OLS & $\begin{array}{l}\text { Negative } \\
\text { Binomial }\end{array}$ & $\begin{array}{l}\text { Negative } \\
\text { Binomial }\end{array}$ \\
\hline Employees in the system & $\begin{array}{c}0.219^{* * *} \\
(0.060)\end{array}$ & $\begin{array}{c}0.209^{* * *} \\
(0.060)\end{array}$ & $\begin{array}{c}0.126^{* * *} \\
(0.032)\end{array}$ & $\begin{array}{c}0.130^{* * *} \\
(0.032)\end{array}$ & $\begin{array}{c}0.064 * * \\
(0.031)\end{array}$ & $\begin{array}{c}0.067^{* *} \\
(0.031)\end{array}$ & $\begin{array}{l}839.706^{*} \\
(443.939)\end{array}$ & $\begin{array}{c}905.404 * * \\
(445.845)\end{array}$ & $\begin{array}{c}0.129 * * * \\
(0.042)\end{array}$ & $\begin{array}{c}0.129^{* * *} \\
(0.042)\end{array}$ \\
\hline $\begin{array}{l}\text { Rural household residence } \\
\text { registration }\end{array}$ & $\begin{array}{c}-0.535 * * * \\
(0.064)\end{array}$ & & $\begin{array}{c}-0.315^{* * *} \\
(0.029)\end{array}$ & & $\begin{array}{c}-0.377 * * * \\
(0.024)\end{array}$ & & $\begin{array}{c}-1,218.814 * * * \\
(330.965)\end{array}$ & & $\begin{array}{c}-0.367 * * * \\
(0.039)\end{array}$ & \\
\hline $\begin{array}{l}\text { Local urban household residence } \\
\text { registration (reference category) }\end{array}$ & & & & & & & & & & \\
\hline $\begin{array}{l}\text { Local rural household residence } \\
\text { registration }\end{array}$ & & $\begin{array}{c}-0.547 * * * \\
(0.070)\end{array}$ & & $\begin{array}{c}-0.356^{* * *} \\
(0.031)\end{array}$ & & $\begin{array}{l}-0.424 * * * \\
(0.025)\end{array}$ & & $\begin{array}{l}-1,109.604 * * * \\
\quad(350.635)\end{array}$ & & $\begin{array}{c}-0.403 * * * \\
(0.042)\end{array}$ \\
\hline $\begin{array}{l}\text { Non-local urban household } \\
\text { residence registration }\end{array}$ & & $\begin{array}{l}-0.131 \\
(0.098)\end{array}$ & & $\begin{array}{c}0.037 \\
(0.052)\end{array}$ & & $\begin{array}{c}0.035 \\
(0.050)\end{array}$ & & $\begin{array}{l}1,263.510 \\
(773.996)\end{array}$ & & $\begin{array}{l}-0.008 \\
(0.073)\end{array}$ \\
\hline $\begin{array}{l}\text { Non-local rural household } \\
\text { residence registration }\end{array}$ & & $\begin{array}{c}-0.560^{* * * *} \\
(0.113)\end{array}$ & & $\begin{array}{c}-0.137 * * * \\
(0.052)\end{array}$ & & $\begin{array}{l}-0.086^{*} \\
(0.047)\end{array}$ & & $\begin{array}{c}-1,271.443 * * \\
(647.666)\end{array}$ & & $\begin{array}{c}-0.218^{* * *} \\
(0.081)\end{array}$ \\
\hline Age & $\begin{array}{l}-0.003 * \\
(0.002)\end{array}$ & $\begin{array}{c}-0.004 * * \\
(0.002)\end{array}$ & $\begin{array}{l}-0.001 \\
(0.001)\end{array}$ & $\begin{array}{l}-0.000 \\
(0.001)\end{array}$ & $\begin{array}{l}-0.005^{* * *} \\
(0.001)\end{array}$ & $\begin{array}{c}-0.003 * * * \\
(0.001)\end{array}$ & $\begin{array}{l}30.444 * * * \\
(9.944)\end{array}$ & $\begin{array}{c}31.904 * * * \\
(10.184)\end{array}$ & $\begin{array}{c}0.000 \\
(0.001)\end{array}$ & $\begin{array}{c}0.001 \\
(0.001)\end{array}$ \\
\hline Undergraduate degree or higher & $\begin{array}{l}-0.117^{*} \\
(0.066)\end{array}$ & $\begin{array}{l}-0.112 * \\
(0.066)\end{array}$ & $\begin{array}{c}0.103 * * * \\
(0.035)\end{array}$ & $\begin{array}{c}0.108 * * * \\
(0.035)\end{array}$ & $\begin{array}{c}0.029 \\
(0.034)\end{array}$ & $\begin{array}{c}0.043 \\
(0.034)\end{array}$ & $\begin{array}{l}2,489.525^{* * *} \\
(521.063)\end{array}$ & $\begin{array}{l}2,420.089 * * * \\
(522.874)\end{array}$ & $\begin{array}{c}0.126 * * * \\
(0.045)\end{array}$ & $\begin{array}{c}0.132 * * * \\
(0.045)\end{array}$ \\
\hline Net household income & $\begin{array}{c}0.000 \\
(0.000)\end{array}$ & $\begin{array}{c}0.000 \\
(0.000)\end{array}$ & $\begin{array}{c}0.000 \\
(0.000)\end{array}$ & $\begin{array}{c}0.000 \\
(0.000)\end{array}$ & $\begin{array}{c}0.000 * * \\
(0.000)\end{array}$ & $\begin{array}{c}0.000 * * \\
(0.000)\end{array}$ & $\begin{array}{c}0.007 * * * \\
(0.001)\end{array}$ & $\begin{array}{c}0.007 * * * \\
(0.001)\end{array}$ & $\begin{array}{c}0.000 \\
(0.000)\end{array}$ & $\begin{array}{c}0.000 \\
(0.000)\end{array}$ \\
\hline Total household net asset & $\begin{array}{c}0.000 * * * \\
(0.000)\end{array}$ & $\begin{array}{c}0.000 * * * \\
(0.000)\end{array}$ & $\begin{array}{c}0.000 * * * \\
(0.000)\end{array}$ & $\begin{array}{c}0.000 * * * \\
(0.000)\end{array}$ & $\begin{array}{c}0.000 * * * \\
(0.000)\end{array}$ & $\begin{array}{c}0.000 * * * \\
(0.000)\end{array}$ & & & $\begin{array}{c}0.000 * * * \\
(0.000)\end{array}$ & $\begin{array}{c}0.000 * * * \\
(0.000)\end{array}$ \\
\hline Male & $\begin{array}{l}-0.072 \\
(0.049)\end{array}$ & $\begin{array}{l}-0.070 \\
(0.049)\end{array}$ & $\begin{array}{c}0.020 \\
(0.024)\end{array}$ & $\begin{array}{c}0.022 \\
(0.024)\end{array}$ & $\begin{array}{c}0.012 \\
(0.023)\end{array}$ & $\begin{array}{c}0.018 \\
(0.023)\end{array}$ & $\begin{array}{c}-701.841 * * \\
(292.620)\end{array}$ & $\begin{array}{c}-723.746 * * \\
(292.913)\end{array}$ & $\begin{array}{c}0.036 \\
(0.032)\end{array}$ & $\begin{array}{c}0.038 \\
(0.032)\end{array}$ \\
\hline Married & $\begin{array}{c}0.080 \\
(0.071)\end{array}$ & $\begin{array}{c}0.074 \\
(0.071)\end{array}$ & $\begin{array}{c}0.033 \\
(0.033)\end{array}$ & $\begin{array}{c}0.037 \\
(0.033)\end{array}$ & $\begin{array}{c}0.045 \\
(0.032)\end{array}$ & $\begin{array}{c}0.051 \\
(0.032)\end{array}$ & $\begin{array}{c}549.229 \\
(397.808)\end{array}$ & $\begin{array}{c}589.044 \\
(398.653)\end{array}$ & $\begin{array}{c}0.135^{* * * *} \\
(0.047)\end{array}$ & $\begin{array}{c}0.136^{* * * *} \\
(0.047)\end{array}$ \\
\hline Family size & $\begin{array}{l}-0.023 \\
(0.019)\end{array}$ & $\begin{array}{l}-0.024 \\
(0.019)\end{array}$ & $\begin{array}{l}-0.013 \\
(0.008)\end{array}$ & $\begin{array}{l}-0.009 \\
(0.008)\end{array}$ & $\begin{array}{l}-0.001 \\
(0.008)\end{array}$ & $\begin{array}{c}0.005 \\
(0.008)\end{array}$ & $\begin{array}{l}-36.063 \\
(89.098)\end{array}$ & $\begin{array}{l}-32.760 \\
(89.489)\end{array}$ & $\begin{array}{l}-0.019^{*} \\
(0.011)\end{array}$ & $\begin{array}{l}-0.017 \\
(0.011)\end{array}$ \\
\hline Financial service worker & $\begin{array}{c}0.137 \\
(0.094)\end{array}$ & $\begin{array}{c}0.139 \\
(0.094)\end{array}$ & $\begin{array}{c}0.141 * * * \\
(0.050)\end{array}$ & $\begin{array}{c}0.143^{* * * *} \\
(0.050)\end{array}$ & $\begin{array}{l}0.093^{*} \\
(0.048)\end{array}$ & $\begin{array}{c}0.095^{* *} \\
(0.048)\end{array}$ & $\begin{array}{c}513.980 \\
(768.098)\end{array}$ & $\begin{array}{c}510.256 \\
(768.080)\end{array}$ & $\begin{array}{c}0.160^{* *} \\
(0.067)\end{array}$ & $\begin{array}{l}0.161 * * \\
(0.067)\end{array}$ \\
\hline Owning a business & $\begin{array}{c}0.032 \\
(0.067)\end{array}$ & $\begin{array}{l}0.035 \\
(0.067)\end{array}$ & $\begin{array}{c}0.078^{* *} \\
(0.032)\end{array}$ & $\begin{array}{c}0.073 * * \\
(0.032)\end{array}$ & & & $\begin{array}{c}47.877 \\
(383.318)\end{array}$ & $\begin{array}{c}39.573 \\
(383.529)\end{array}$ & $\begin{array}{c}0.012 \\
(0.045)\end{array}$ & $\begin{array}{c}0.009 \\
(0.045)\end{array}$ \\
\hline Homeowner & $\begin{array}{c}0.164 * * \\
(0.081)\end{array}$ & $\begin{array}{l}0.158^{*} \\
(0.082)\end{array}$ & & & & & $\begin{array}{c}1,013.886 * * \\
(444.236)\end{array}$ & $\begin{array}{c}1,044.856^{* *} \\
(447.657)\end{array}$ & $\begin{array}{l}0.086^{*} \\
(0.051)\end{array}$ & $\begin{array}{l}0.097^{*} \\
(0.051)\end{array}$ \\
\hline Credit card & $\begin{array}{c}0.424 * * * \\
(0.056)\end{array}$ & $\begin{array}{c}0.424 * * * \\
(0.056)\end{array}$ & $\begin{array}{c}0.286 * * * \\
(0.030)\end{array}$ & $\begin{array}{c}0.287 * * * \\
(0.030)\end{array}$ & $\begin{array}{c}0.275^{* * * *} \\
(0.028)\end{array}$ & $\begin{array}{c}0.277 * * * \\
(0.028)\end{array}$ & $\begin{array}{c}3,699.380 * * * \\
(408.953)\end{array}$ & $\begin{array}{c}3,681.254 * * * \\
(409.078)\end{array}$ & $\begin{array}{c}0.299 * * * \\
(0.038)\end{array}$ & $\begin{array}{c}0.300^{* * *} \\
(0.038)\end{array}$ \\
\hline Rural & $\begin{array}{c}-0.331 * * * \\
(0.072)\end{array}$ & $\begin{array}{c}-0.326 * * * \\
(0.073)\end{array}$ & $\begin{array}{c}-0.284 * * * \\
(0.031)\end{array}$ & $\begin{array}{c}-0.258 * * * \\
(0.031)\end{array}$ & & & $\begin{array}{c}316.222 \\
(329.707)\end{array}$ & $\begin{array}{c}275.805 \\
(336.981)\end{array}$ & $\begin{array}{c}-0.281 * * * \\
(0.041)\end{array}$ & $\begin{array}{c}-0.260 * * * \\
(0.042)\end{array}$ \\
\hline $\begin{array}{l}\text { In east region (reference } \\
\text { category) }\end{array}$ & & & & & & & & & & \\
\hline In west region & $-0.150 *$ & $-0.153 *$ & $-0.156^{* * *}$ & $-0.144 * * *$ & $-0.237 * * *$ & $-0.208 * * *$ & $-1,129.637^{* * *}$ & $-1,117.139^{* * *}$ & $-0.128 * * *$ & $-0.120 * *$ \\
\hline
\end{tabular}




\begin{tabular}{|c|c|c|c|c|c|c|c|c|c|c|}
\hline & $(0.082)$ & $(0.082)$ & $(0.038)$ & $(0.038)$ & $(0.035)$ & $(0.035)$ & (396.508) & (398.133) & $(0.049)$ & $(0.050)$ \\
\hline In central region & $\begin{array}{c}-0.382 * * * \\
(0.060)\end{array}$ & $\begin{array}{c}-0.388^{* * *} \\
(0.060)\end{array}$ & $\begin{array}{c}-0.054 * * \\
(0.027)\end{array}$ & $\begin{array}{l}-0.041 \\
(0.027)\end{array}$ & $\begin{array}{c}-0.052^{* *} \\
(0.025)\end{array}$ & $\begin{array}{l}-0.028 \\
(0.025)\end{array}$ & $\begin{array}{l}-996.237 * * * \\
(306.966)\end{array}$ & $\begin{array}{c}-977.826 * * * \\
(309.759)\end{array}$ & $\begin{array}{l}-0.032 \\
(0.037)\end{array}$ & $\begin{array}{l}-0.024 \\
(0.037)\end{array}$ \\
\hline In northeast region & $\begin{array}{c}-0.441 * * * \\
(0.080)\end{array}$ & $\begin{array}{c}-0.448 * * * \\
(0.081)\end{array}$ & $\begin{array}{c}-0.295^{* * *} \\
(0.037)\end{array}$ & $\begin{array}{c}-0.287 * * * \\
(0.037)\end{array}$ & $\begin{array}{c}-0.279 * * * \\
(0.035)\end{array}$ & $\begin{array}{c}-0.264 * * * \\
(0.035)\end{array}$ & $\begin{array}{c}-1,689.336^{* * *} \\
(408.039)\end{array}$ & $\begin{array}{c}-1,644.766^{* * *} \\
(409.946)\end{array}$ & $\begin{array}{c}-0.342 * * * \\
(0.048)\end{array}$ & $\begin{array}{c}-0.338 * * * \\
(0.048)\end{array}$ \\
\hline \multicolumn{11}{|l|}{$\begin{array}{l}\text { In low risk preference (reference } \\
\text { category) }\end{array}$} \\
\hline In central risk preference & $\begin{array}{c}0.111 * * \\
(0.053)\end{array}$ & $\begin{array}{c}0.112 * * \\
(0.053)\end{array}$ & $\begin{array}{c}0.108 * * * \\
(0.025)\end{array}$ & $\begin{array}{c}0.108 * * * \\
(0.025)\end{array}$ & $\begin{array}{c}0.129 * * * \\
(0.024)\end{array}$ & $\begin{array}{c}0.129 * * * \\
(0.024)\end{array}$ & $\begin{array}{c}628.761 * * \\
(302.679)\end{array}$ & $\begin{array}{c}621.401 * * \\
(302.697)\end{array}$ & $\begin{array}{c}0.124 * * * \\
(0.033)\end{array}$ & $\begin{array}{c}0.125^{* * *} \\
(0.033)\end{array}$ \\
\hline In high risk preference & $\begin{array}{c}0.406^{* * * *} \\
(0.063)\end{array}$ & $\begin{array}{c}0.408 * * * \\
(0.063)\end{array}$ & $\begin{array}{c}0.151 * * * \\
(0.031)\end{array}$ & $\begin{array}{c}0.149 * * * \\
(0.031)\end{array}$ & $\begin{array}{c}0.189 * * * \\
(0.029)\end{array}$ & $\begin{array}{c}0.185 * * * \\
(0.029)\end{array}$ & $\begin{array}{c}2,095.165^{* * * *} \\
(389.514)\end{array}$ & $\begin{array}{c}2,079.658 * * * \\
(389.647)\end{array}$ & $\begin{array}{c}0.153 * * * \\
(0.041)\end{array}$ & $\begin{array}{c}0.152 * * * \\
(0.041)\end{array}$ \\
\hline $\begin{array}{l}\text { Prefer future consumption to } \\
\text { present }\end{array}$ & $\begin{array}{c}0.001 \\
(0.050)\end{array}$ & $\begin{array}{c}0.003 \\
(0.050)\end{array}$ & $\begin{array}{c}0.051^{* *} \\
(0.023)\end{array}$ & $\begin{array}{c}0.052^{* *} \\
(0.023)\end{array}$ & $\begin{array}{c}0.052^{* *} \\
(0.022)\end{array}$ & $\begin{array}{c}0.053^{* *} \\
(0.022)\end{array}$ & $\begin{array}{c}-34.953 \\
(272.410)\end{array}$ & $\begin{array}{c}-40.659 \\
(272.419)\end{array}$ & $\begin{array}{l}0.056^{*} \\
(0.032)\end{array}$ & $\begin{array}{l}0.057^{*} \\
(0.032)\end{array}$ \\
\hline Constant & $\begin{array}{c}-0.744 * * * \\
(0.138)\end{array}$ & $\begin{array}{c}-0.698 * * * \\
(0.145)\end{array}$ & $\begin{array}{c}0.265^{* * * *} \\
(0.061)\end{array}$ & $\begin{array}{c}0.206^{* * *} \\
(0.064)\end{array}$ & $\begin{array}{c}0.460 * * * \\
(0.058)\end{array}$ & $\begin{array}{c}0.359 * * * \\
(0.061)\end{array}$ & $\begin{array}{c}-1,176.828 \\
(778.569)\end{array}$ & $\begin{array}{c}-1,383.650^{*} \\
(817.807)\end{array}$ & $\begin{array}{l}-0.171^{*} \\
(0.091)\end{array}$ & $\begin{array}{c}-0.215^{* *} \\
(0.095)\end{array}$ \\
\hline $\begin{array}{l}\text { Observations } \\
\text { Adjusted } \mathrm{R}^{2}\end{array}$ & 4,369 & 4,369 & 8,016 & 8,016 & 8,016 & 8,016 & $\begin{array}{l}8,016 \\
0.056\end{array}$ & $\begin{array}{l}8,016 \\
0.056\end{array}$ & 8,016 & 8,016 \\
\hline Pseudo $\mathrm{R}^{2}$ & 0.169 & 0.169 & 0.086 & 0.087 & 0.077 & 0.078 & & & 0.084 & 0.085 \\
\hline
\end{tabular}

Standard errors in parentheses
$* * * \mathrm{p}<0.01, * * \mathrm{p}<0.05, * \mathrm{p}<0.1$ 